\title{
Impact of written information on control and adherence in type 2 diabetes
}

\author{
Inês Rosendo Carvalho e Silva Caetano ${ }^{1 *} \odot$, Luiz Miguel Santiago ${ }^{2}$, Margarida Marques ${ }^{3}$ \\ ${ }^{1}$ Unidade de Saúde Familiar (USF) Coimbra Centro, Faculdade de Medicina da Universidade de Coimbra, Coimbra, Portugal \\ ${ }^{2}$ PhD Professor. USF Topázio, Faculdade de Medicina da Universidade de Coimbra, Coimbra, Portugal \\ ${ }^{3}$ Biostatistics Laboratory, Faculdade de Medicina da Universidade de Coimbra, Coimbra, Portugal
}

Study conducted at Faculdade de Medicina da Universidade de Coimbra, Coimbra, Portugal

Article received: 6/2/2017 Accepted for publication: 7/16/2017

*Correspondence: Address: Rua Larga, 3.000 Coimbra - Portugal Postal code: $3004-504$ inesrcs@gmail.com

\section{SUMMARY}

Introduction: Diabetes therapeutic education and information by leaflets is important. This study aimed to understand the effectiveness of written information to diabetic patients, after six months, in the control of diabetes and medication adherence.

Method: Non-pharmacological clinical trial. Randomized sample of diabetic patients of 65 volunteer doctors, distributed among the five health regions in Portugal. At the first appointment, patients were randomized in four groups (three intervention with validated leaflets and one control), leaflet reading being reinforced at the follow-up appointments in a 6 -months period. Variables collected: $\mathrm{HbA}_{1 \mathrm{c}}$, home blood glucose, weight, waist circumference, blood pressure, cigarettes smoked, physical activity level, adherence to medication, medication, height, diabetes progression, age, sex and educational background. Descriptive and inferential statistics.

Results: From the 709 patients recruited, 702 were studied in this 6-months period with no statistical differences in the baseline variables studied. After six months of intervention, the adherence to medication improved in the leaflet group $(\mathrm{p}=0.034)$ This was noticed in those under 65 years of age $(\mathrm{p}=0.027)$, with diabetes for $\leq 5$ years $(\mathrm{p}=0.010)$, with educational background up to 4 years $(\mathrm{p}=0.030)$ and 9 years $(\mathrm{p}=0.006)$ and with $\mathrm{HbA}_{1 \mathrm{c}} \geq 7 \%$ at the beginning of the study.

Conclusion: Interventions with leaflets handed in primary healthcare to people with diabetes type 2 can bring benefits in what concerns adherence to therapeutics, namely in younger people with a less studies.

Keywords: Diabetes Mellitus. Medication Adherence. Patient Education as Topic.

\section{INTRODUCTION}

Diabetes may become one of the leading causes of morbidity and total/partial disability in the $21^{\text {st }}$ century, with an estimated 642 million diabetics by $2040 .{ }^{1}$

Good glycemic control in diabetes is essential for retarding microvascular and neuropathic complications and, if initiated in time, macrovascular complications as well. ${ }^{2-9} \mathrm{In}$ diabetes, decreasing blood pressure values decreases mortality, the risk of cardiovascular events, albuminuria and retinopathy, ${ }^{5,10,11}$ Other cardiovascular risk factors with an impact on mortality include dyslipidemia ${ }^{12}$ and smoking habits, with an NNT of 11 to 10 years in reducing mortality. ${ }^{13}$

It is known that many people with diabetes do not achieve the goals recommended for controlling their disease.${ }^{1416}$ Following health professionals' recommenda- tions ${ }^{17,18}$ and patients' adherence to pharmacological measures, ${ }^{19,20}$ as well as their lifestyles, ${ }^{21-23}$ are far from desirable.

A structured educational intervention appears to be beneficial to people with diabetes in the short term in improving not only their knowledge, but also markers such as glycated hemoglobin $\left.\left(\mathrm{HbA}_{1 \mathrm{c}}\right)\right)^{24,25}$ blood pressure, and blood lipids. ${ }^{26,27}$ Interventions targeted at multiple behaviors and done in primary health care seem to be promising. ${ }^{28}$ Leaflet intervention seems to have a positive effect on knowledge, ${ }^{29-31}$ adherence to treatment in short-term treatments ${ }^{32}$ and physicianperson communication, leading to greater shared discussion. ${ }^{33}$

There are few published studies on written information given to people with diabetes, particularly in primary care. Those that do exist refer to improvement in $\mathrm{HbA}_{1 \mathrm{c}}$ levels, ${ }^{34-37}$ postprandial glycemia ${ }^{38}$ and adherence to treatment. ${ }^{39}$ 
We thus carried out this study to evaluate the effectiveness of the information given to the person with diabetes by means of leaflets and compare the results with those of a control group that only received the usual advice given during medical visits. Our objective was also to check whether there are differences among leaflets about diabetes, its treatment and the importance of physical activity in controlling the disease. We also sought to determine if the impact of the intervention was anyhow influenced by gender, age, academic background, diabetes progression time and initial control of $\mathrm{HbA}_{1 c}$.

\section{Method}

Non-pharmacological clinical trial conducted as a prospective, randomized, controlled, non-blind and multicenter study with type 2 diabetes patients receiving primary care. Those who agreed to participate were included if they could read or had someone in the household who could read the leaflet to them. Persons who already had a relative or coinhabitant participating in the study, those under 18, pregnant, bedridden or wheelchair-bound, and all those with a diagnosis of depression were excluded.

The sample size calculation $(\mathrm{n}=1,170)$ was based on a previous study done in the central region of Portugal, ${ }^{40}$ with significance level $[\alpha]=0.05,[\beta]=0.20$, study power $1-[\beta]=0.80(\mathrm{n}=175$ for each group $)$, including a $10 \%$ margin for dropouts. The sample consisted of the first 18 people with type 2 diabetes who had a consultation with their general practitioner (family physician), as from October 15,2014 . The individuals were randomized according to their order of arrival by using random numbers generated by computer software in four groups: 585 sample units were given a validated leaflet (195 on diabetes, 195 on diabetes treatment, 195 on the importance of physical activity in diabetes management), and the other 585 were not given any of the leaflets and received the usual care.

General practitioners were invited over social media. Voluntaries were accepted until they reached 65 doctors from continental Portugal, distributed across the five areas (25 in the North, 11 in the Center, 23 in Lisbon and Vale do Tejo, three in Alentejo, and three others in Algarve).

The intervention was done at the first visit: the leaflet was delivered and the person receiving it was asked to read it or to have someone else read it to them at home. They were asked to try and understand the information contained therein. At each subsequent visit, the request for reading the brochure was reinforced and any queries were answered.

The variables collected throughout the visits were: $\mathrm{HbA}_{1 \mathrm{c}}(\%)$, capillary glycemia was recorded in the outpa- tient clinic over the past four months both while fasting and in the postprandial period - the readings were then classified as controlled (all those within the $70-130 \mathrm{mg} / \mathrm{dL}$ were classified as fasting and all others $<180 \mathrm{mg} / \mathrm{dL}$ as postprandial) or uncontrolled; weight $(\mathrm{kg})$; abdominal perimeter along the iliac crests in the horizontal position (AP, $\mathrm{cm}$ ); blood pressure (BP, $\mathrm{mmHg}$ ); smoking habits (number of cigarettes/day); physical activity (PACE instrument scale, validated in Portuguese); ${ }^{41}$ adherence to the pharmacological treatment of diabetes (MAT scale, validated in Portuguese, ${ }^{42}$ consisting of seven questions 1-6, with the total score of 42 corresponding to maximum adherence); medications for diabetes and high blood pressure; insulin medication; reading of the leaflet. The variables collected at the beginning and end were: height (meters), diabetes progression time (years), age (years), sex, education (number of school years).

The leaflets were previously validated following content development according to the existing recommendations, ${ }^{43,44}$ reviewed by 14 scientific experts and one Portuguese-language expert. Subsequently, they were qualitatively evaluated by ten people with type 2 diabetes having different levels of education.

Statistical analysis was performed with the purpose of analyzing the impact of six months following the intervention: we compared the beginning-end differences between the intervention and control groups, by using the Mann-Whitney $\mathrm{U}$ test, and among the various groups of leaflets, by using the Kruskal-Wallis test. We performed the same analysis of the intervention's impact at the six months across subgroups by sex, age, level of schooling, diabetes duration, and initial $\mathrm{HbA}_{1 \mathrm{c}}$ levels. The significance level we adopted in all tests was 0.05 .

A text about the study was previously made available to each participant user, whose informed consent was requested in writing. We then gave them two copies of the form, one of which we requested in return once the participants had signed it. Our study received a positive opinion from the ethics committees of Faculdade de Medicina at Universidade de Coimbra, from continental Portugal's Regional Health Administrations (Administrações Regionais de Saúde, ARS) and from the National Commission on Data Protection (Comissão Nacional de Proteção de Dados).

\section{RESULTS}

\section{Initial sample}

The initial sample consisted of 709 people with diabetes recruited by 41 general practitioners throughout Portugal. In it, $60.2 \%$ of the people were males, the average age was 
$66.12 \pm 10.47$ years, and the mean number of school years was $6.26 \pm 3.90$, whereas $1.7 \%$ were illiterate. They had had diabetes for $9.25 \pm 7.83$ years on average, $13.0 \%$ were insulin-treated, the mean $\mathrm{HbA}_{1 \mathrm{c}}$ was $6.79 \% \pm 1.04 \%$, and $65.7 \%$ had a controlled disease $\left(\mathrm{HbA}_{1 \mathrm{c}}<7 \%\right)$. There were no outpatient records for glycemia in $41.6 \%$ of participants while fasting versus $52 \%$ of them postprandially. Total adherence to treatment was found in $34.4 \%$ of them (42 points on the MAT scale), ${ }^{42}$ with $90 \%$ adhering to medication (value $\geq$ 5). ${ }^{45-47}$ Blood pressure was controlled (BP $<140 / 90$ ) in $54.6 \%$ of participants, the mean BMI was $29.39 \pm 4.87 \mathrm{~kg} / \mathrm{m}^{2}$, BP was high in $88.3 \%$ of females and $72.1 \%$ of males. Relative to their lifestyle, $71.1 \%$ reported practicing physical activity, $26.2 \%$ of them five or more times per week, $10.6 \%$ were smokers with an average of $16.39 \pm 10.11$ cigarettes/day.

\section{Intervention}

Of the 709 people recruited, follow-up of 702 continued up to six months (Figure 1). There were no significant differences between the initial and final samples, as well as no differences between the intervention and control groups, across groups according to the type of leaflet distributed $(\mathrm{p}=0.991)$ or among those who reported either having read the leaflet at home or not $(\mathrm{p}=0.691)$.

Comparing the intervention group with the control group, after six months, we found a significant improvement in adherence to treatment ( $\mathrm{p}=0.034)$, as shown in Table 1 . There were no significant differences between the variables at the beginning and end across the various groups of leaflets.

\section{Complementary analysis}

We repeated the analysis including only those who reported having read the leaflets and the results were similar across groups for changes in antidiabetic and antihypertensive medication.

In the subgroup analysis, we found improvement in adherence to treatment in the intervention group: in the

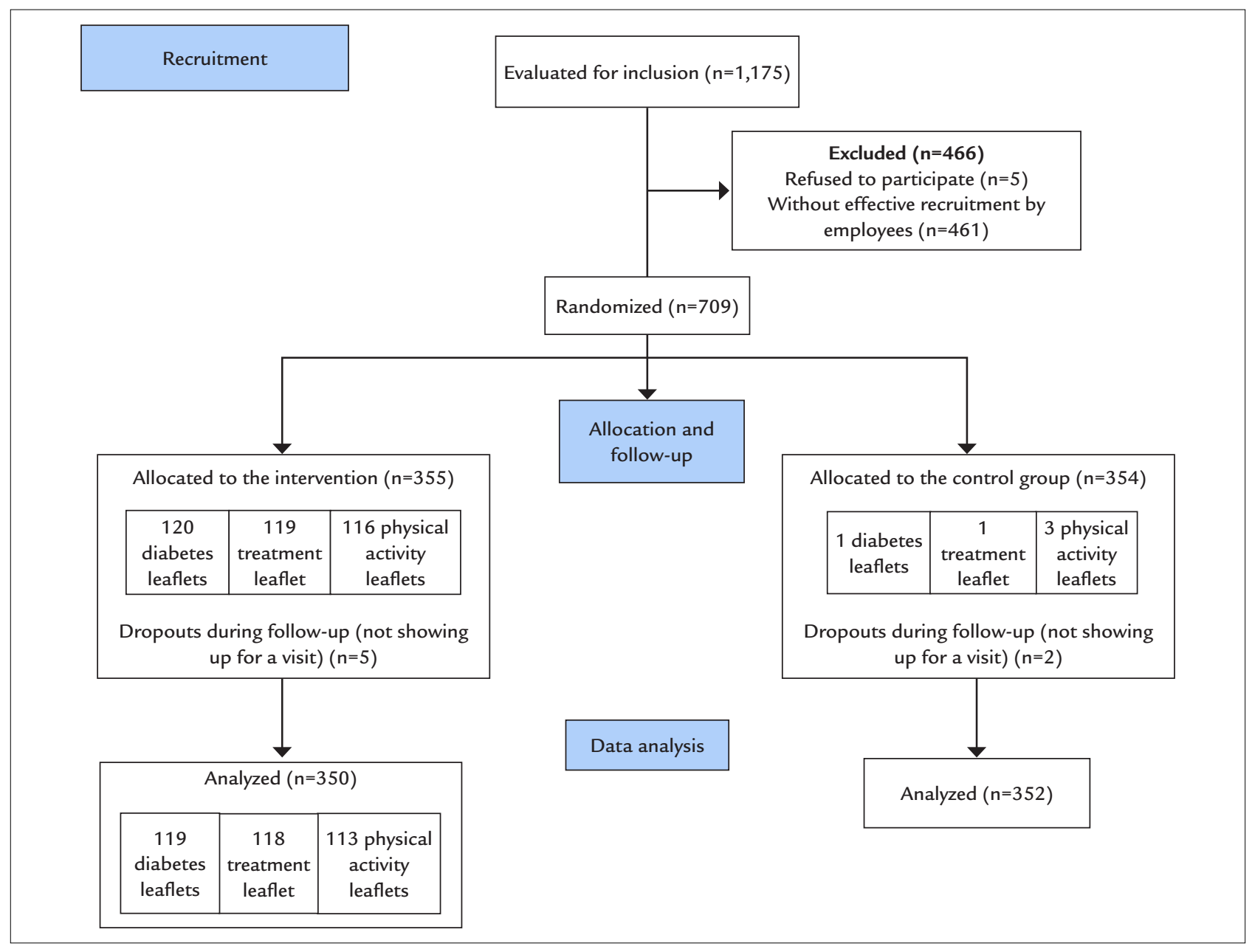

FIGURE 1 CONSORT diagram used to the study. 


\begin{tabular}{|c|c|c|c|c|c|c|}
\hline Variable & Time & Control group & Intervention group & Total & $\mathbf{n}$ & $\mathbf{p}^{*}$ \\
\hline \multirow[t]{2}{*}{$\mathrm{HbA}_{1 \mathrm{c}}(\%)$} & Baseline & $6.74 \pm 0.97$ & $6.85 \pm 1.10$ & $6.79 \pm 1.04$ & \multirow[t]{2}{*}{633} & \multirow[t]{2}{*}{0.898} \\
\hline & Final & $6.84 \pm 1.04$ & $6.85 \pm 0.99$ & $6.85 \pm 1.02$ & & \\
\hline \multirow[t]{2}{*}{ Systolic BP (mmHg) } & Baseline & $137.41 \pm 17.09$ & $136.77 \pm 15.83$ & $137.09 \pm 16.47$ & \multirow[t]{2}{*}{693} & \multirow[t]{2}{*}{0.078} \\
\hline & Final & $134.75 \pm 16.02$ & $136.29 \pm 17.16$ & $135.51 \pm 16.60$ & & \\
\hline \multirow[t]{2}{*}{ Diastolic BP (mmHg) } & Baseline & $76.50 \pm 10.90$ & $76.60 \pm 10.31$ & $76.55 \pm 10.61$ & \multirow[t]{2}{*}{689} & \multirow[t]{2}{*}{0.522} \\
\hline & Final & $75.43 \pm 10.81$ & $76.22 \pm 10.42$ & $75.83 \pm 10.61$ & & \\
\hline \multirow[t]{2}{*}{$\operatorname{BMI}\left(\mathrm{kg} / \mathrm{m}^{2}\right)$} & Baseline & $29.50 \pm 4.75$ & $29.25 \pm 5.00$ & $29.37 \pm 4.88$ & \multirow[t]{2}{*}{686} & \multirow[t]{2}{*}{0.627} \\
\hline & Final & $29.31 \pm 4.79$ & $29.14 \pm 4.94$ & $29.23 \pm 4.86$ & & \\
\hline \multirow[t]{2}{*}{ Abdominal perimeter $(\mathrm{cm})$} & Baseline & $102.89 \pm 11.29$ & $102.30 \pm 11.67$ & $102.60 \pm 11.47$ & \multirow[t]{2}{*}{563} & \multirow[t]{2}{*}{0.783} \\
\hline & Final & $102.48 \pm 11.97$ & $101.84 \pm 11.75$ & $102.16 \pm 11.85$ & & \\
\hline \multirow[t]{2}{*}{ Treatment adherence } & Baseline & $39.80 \pm 2.76$ & $39.63 \pm 2.92$ & $39.72 \pm 2.84$ & \multirow[t]{2}{*}{608} & \multirow[t]{2}{*}{0.034} \\
\hline & Final & $40.22 \pm 2.63$ & $40.22 \pm 2.47$ & $40.22 \pm 2.56$ & & \\
\hline \multirow[t]{2}{*}{ Physical activity } & Baseline & $3.43 \pm 1.67$ & $3.59 \pm 1.69$ & $3.51 \pm 1.68$ & \multirow[t]{2}{*}{654} & \multirow[t]{2}{*}{0.943} \\
\hline & Final & $3.31 \pm 1.55$ & $3.57 \pm 1.71$ & $3.44 \pm 1.63$ & & \\
\hline \multirow{2}{*}{$\begin{array}{l}\text { Controlled outpatient fasting } \\
\text { blood glucose }\end{array}$} & Baseline & $45.5 \%$ & $41.8 \%$ & $43.8 \%$ & 409 & \multirow[t]{2}{*}{0.482} \\
\hline & Final & $46.9 \%$ & $45.1 \%$ & $46 \%$ & 389 & \\
\hline \multirow{2}{*}{$\begin{array}{l}\text { Controlled outpatient post-prandial } \\
\text { blood glucose }\end{array}$} & Baseline & $40.3 \%$ & $34 \%$ & $37.3 \%$ & 335 & \multirow[t]{2}{*}{0.270} \\
\hline & Final & $40.8 \%$ & $42.3 \%$ & $41.5 \%$ & 337 & \\
\hline \multirow{2}{*}{$\begin{array}{l}\text { Number of cigarettes/day } \\
\text { (smokers only) }\end{array}$} & Baseline & $15.92 \pm 9.47$ & $16.64 \pm 10.83$ & $16.33 \pm 10.183$ & \multirow[t]{2}{*}{54} & \multirow[t]{2}{*}{0.739} \\
\hline & Final & $14.09 \pm 11.07$ & $13.74 \pm 12.15$ & $13.89 \pm 11.60$ & & \\
\hline
\end{tabular}

*Mann-Whitney $\mathrm{U}$ test (for non-normal distribution).

$\mathrm{HbA}_{1 c}$ : glycated hemoglobin $\left(\mathrm{HbA}_{1 c}\right)$; $\mathrm{BMI}$ : body mass index; $\mathrm{BP}$ : blood pressure.

population under 65 years of age $(\mathrm{p}=0.027)$, in the population having up to four school years and also in those with up to nine years of formal education ( $\mathrm{p}=0.030$ and $\mathrm{p}=0.006$, respectively). We also observed this improvement in participants who had had diabetes for $\leq 5$ years $(\mathrm{p}=0.010)$, but not in the other diabetes duration subgroups nor in those with uncontrolled $\mathrm{HbA}_{1 \mathrm{c}}$ at the beginning of the study $\left(\mathrm{HbA}_{1 \mathrm{c}} \geq 7 \%\right)(\mathrm{p}=0.008)$.

Systolic blood pressure decreased more notably in the control group ( $\mathrm{p}=0.046$ ). The same observation applies to the individuals who had had DM2 for $\leq 5$ years and $\leq 7$ years ( $\mathrm{p}=0.025$ and $\mathrm{p}=0.018$, respectively) and also in those with controlled $\mathrm{HbA}_{1 \mathrm{c}}(<7 \%)$ at the beginning of the study $(\mathrm{p}=0.046)$.

Among leaflets, as shown in Table 2, we found differences among participants with up to nine years of formal education, whose adherence to treatment improved upon receiving the leaflets about the disease compared to others $(\mathrm{p}=0.023)$. In people with more than nine years of formal education, postprandial capillary glycemia results progressed more positively among outpatient participants than it did among those who received the leaflet about physical activity leaflet $(\mathrm{p}=0.023)$.

\section{Discussion}

One of our study's limitations is interobserver bias, as there were 41 investigators involved in taking measurements, using scales and administering the intervention. An attempt to minimize this was made by means of on-site face-to-face meetings and detailed written instructions. The choice of variables was limited, and no other sociodemographic or risk factors were included. Neither were factors that could characterize the participants' dietary and nutritional habits, diabetes complications, polypharmacy or multimorbidity that could influence adherence to treatment and control of the disease so as to avoid work overload among investigators, who contributed to our study as volunteers. Still, there were many who did not report recruitment data, as there were also participants with diabetes who did not show up for a visit. All things being considered, at the end of six months, we obtained only $60 \%$ of the initially calculated sample.

The study is performance-biased due to its non-blinded method, which is inherent in a non-pharmacological clinical trial with educational intervention in the real world. The control group itself always receives some sort of educational intervention (it would be unethical if it 
TABLE 2 Differences across the various groups of leaflets under analysis of subgroups of people having more than or fewer than nine years of formal education at the beginning of the study and at six months.

\begin{tabular}{|c|c|c|c|c|c|c|c|c|}
\hline Variable & Time & $\begin{array}{l}\text { Control } \\
\text { group }\end{array}$ & $\begin{array}{l}\text { Diabetes } \\
\text { leaflet group }\end{array}$ & $\begin{array}{l}\text { Treatment } \\
\text { leaflet group }\end{array}$ & $\begin{array}{l}\text { Physical activity } \\
\text { leaflet group }\end{array}$ & Total & $\mathbf{n}$ & $\begin{array}{l}\mathrm{P}^{*} \text { (among } \\
\text { groups) }\end{array}$ \\
\hline \multirow{2}{*}{$\begin{array}{l}\text { Treatment adherence } \\
\text { ( } \leq 9 \text { years of formal education) }\end{array}$} & Baseline & $39.84 \pm 2.60$ & $39.72 \pm 2.77$ & $39.53 \pm 2.76$ & $39.86 \pm 2.60$ & $39.78 \pm 2.65$ & \multirow[t]{2}{*}{497} & \multirow[t]{2}{*}{0.023} \\
\hline & Final & $40.18 \pm 2.49$ & $40.23 \pm 2.47$ & $40.29 \pm 2.29$ & $40.28 \pm 2.22$ & $40.22 \pm 2.41$ & & \\
\hline \multirow{2}{*}{$\begin{array}{l}\text { Controlled outpatient } \\
\text { post-prandial blood glucose } \\
\text { (>9 years of formal education) }\end{array}$} & Baseline & $26.7 \%$ & $33.3 \%$ & $66.7 \%$ & $14.3 \%$ & $34.5 \%$ & \multirow[t]{2}{*}{53} & \multirow[t]{2}{*}{0.023} \\
\hline & Final & $35.7 \%$ & $33.3 \%$ & $45.5 \%$ & $57.1 \%$ & $40 \%$ & & \\
\hline
\end{tabular}

did not), even if such intervention is not structured exactly the same way. This consequently limits the magnitude of the results and the drawing of conclusions. ${ }^{48,49} \mathrm{In}$ addition, the study was carried out during a period of six months of observation only, which therefore prevents any assessments of the consequences diabetes has on health.

This methodology led to losses as far as control of variables was concerned, but allowed for gains in perceiving the applicability of the intervention. It was a simple and replicable intervention, as recommended elsewhere in the literature, ${ }^{26,28,50}$ of low intensity and medium duration, and is more likely to have an impact on the health of populations. ${ }^{51}$ On the other hand, more complex or group interventions, in turn, imply more motivated people failing to reach the general population. ${ }^{52,53}$

This was the first national clinical trial in primary health care to be conducted in Portugal and, although the sample did not have the desired size at six months, the groups did have a distribution with no significant differences, which increases the power of the conclusions we can draw.

\section{Intervention results}

Six months after intervention, adherence to pharmacological therapy improved significantly in the leaflet group $(\mathrm{p}=0.034)$. Other studies, analyzing the impact of written information given out to people with diabetes on adherence pharmacological treatment at three months, also showed improvements. ${ }^{37,39,54} \mathrm{~A}$ review by Cochrane ${ }^{32}$ also states that written information is useful in short-term treatments. It would be presumably logical that these results implied improvement in glycemic control. ${ }^{15,55-60}$ In our study, glycemic control worsened in the control group (from $6.74 \%$ to $6.84 \% \mathrm{HbA}_{1 \mathrm{c}}$ ), whereas it remained unchanged in the intervention group (mean $6.85 \%$ ), but without any difference $(\mathrm{p}=0.888)$. This was also observed in other studies. ${ }^{61}$ We are left to wonder what the level of adherence to be achieved will be in order to improve metabolic control and to what extent other factors may have influenced this control, such as adherence to physical activity (which worsened over six months) or to diet (which has not been studied). These are some of the questions that should still be resolved. It is known that, regardless of metabolic control, nonadherence to medication seems to have more micro- and macrovascular complications, ${ }^{62}$ as well as increased risk of hospitalization and death..$^{52,62-65}$ Thus, it is important to consider interventions such as this one in populations like younger people, with diabetes for a shorter period of time, with less formal education, and with uncontrolled $\mathrm{HbA}_{1 c}$.

The fact that older people did not experience an improvement can be explained by multimorbidity and chronic polypharmacy and less literacy. The leaflet on treatment appeared to be specifically more beneficial for people with less schooling. Among people with more schooling, in turn, the leaflet on physical activity was the one with the greatest impact on postprandial glycemias, which were shown to be more related to the complications from diabetes and cardiovascular mortality than were $\mathrm{HbA}_{1 \mathrm{c}}$ and fasting glycemia. ${ }^{66}$ In addition, physical exercise proved to specifically and effectively decrease postprandial glycemias. ${ }^{67}$ This difference in impact on people with more schooling may be due to a greater ease in perceiving the relation between exercise and postprandial glycemia.

As limiting factors of more robust results, we can mention the low level of literacy, ${ }^{68,69}$ even though we do not yet know which type of intervention would be the most beneficial to the Portuguese population. ${ }^{70,71}$ The use of written materials seems to improve literacy and health behaviors. ${ }^{72}$ In order to analyze the results, it is not necessary to neglect the fact that the intervention was done by the general practitioner who is already familiar to the person with diabetes and with whom he or she has an established relationship. It is known that educational interventions, when made by a single person, seem to yield better results. There are studies showing that there is no relation between knowledge and better metabolic 
control $^{73-75}$ in diabetes. Nevertheless, educational interventions are related to this control, ${ }^{52}$ which suggests that there is more to influencing this variable than solely transmitted knowledge. ${ }^{24,25}$

The leaflets' lack of customization to the needs of each person ${ }^{76,77}$ and the short contact time between educator and the person with diabetes (because the leaflet was read at home) may have led to lesser efficacy of the intervention. ${ }^{24}$ There also appears to be greater effectiveness of educational interventions when these are more often repeated over time, at short intervals. ${ }^{49,78}$ Accordingly, the fact that the leaflets were delivered only at the beginning of our study may have triggered a poorer effect on its potential benefit.

It will be important to conduct longer follow-up studies to perceive the impact of educational interventions on morbidity and mortality and also studies with more frequent and ongoing interventions that can help identify the most effective type of intervention in populations with low health literacy.

\section{Conclusion}

Written information given to people with diabetes by their general practitioner did not have a statistically significant impact on metabolic control. However, it did increase adherence to pharmacological treatment six months later compared to usual counseling given at the visits $(\mathrm{p}=0.034)$.

We found differences among people with diabetes who received the various leaflets and also in those individuals with up to nine years of formal education. Improvement in adherence to treatment was significantly greater in those who received the leaflet $(\mathrm{p}=0.023)$.

In those with more than nine years of formal education, the outpatient postprandial glycemias were better than in those who received leaflets on physical activity $(\mathrm{p}=0.023)$. Leaflet impact was influenced by age, academic background, duration of diabetes, and glycemic control at the beginning of the study. It improved adherence to treatment in people younger than 65 years $(\mathrm{p}=0.027)$, who had had diabetes for five years or less $(\mathrm{p}=0.010)$, with up to four $(\mathrm{p}=0.030)$ and up to nine years of formal education $(\mathrm{p}=0.006)$, and with $\mathrm{HbA}_{1 \mathrm{c}} \geq 7 \%$ at the beginning of the study $(\mathrm{p}=0.008)$.

In Portugal, it will be interesting to have validated leaflets to be distributed by health professionals during the follow-up visits to this population.

\section{ACKNOWLEDGMENTS}

The authors would like to thank all the health units and general practitioners who collaborated in recruiting and collecting data: Dagmara Paiva, João Monteiro, Manuel
Tinoco, Ângela Neves, Raquel Braga, Maria José Teixeira, Carla Costa, Carla Morna, Maria Margarida Moreira, José Rui Caetano, Francisco Fachado, Lina Costa, Daniela Neves, Mónica Granja, Gabriela Poças, Helena Oliveira, Paulo Sousa Neves, Severina Nicora, Dilermando Sobral, José Augusto Simões, Celina Pires Rosa, Raquel Ferreira, Pedro Salgado Gomes, Ana Sofia Tavares, Helena Carvalho, António Pereira, Miguel Pereira, Vasco Queiroz, Liliana Constantino, Joana Azeredo, Luísa Carvalho, Paula Cristina Silva, Joana Abreu, Maria de Lurdes Tavares Bello, Tatiana Petrachi, Maria José Verdasca, Maria do Rosário Gonçalves, Andreia Luís, Marta Marquês, Joana Luís, Ana Andreia Matos, Raquel Henriques, Jaime Brito da Torre, Cineyde Barros, Natalyia Barchuk, Nuno Jacinto, Laura Gonçalves, Hermínia Caeiro, Viktoriia Vinagre, Nelson Brito, Margarida Feteira, Rui Miranda, Susana Costa.

\section{Resumo}

Impacto da informação escrita no controle e adesão na diabetes tipo 2

Introdução: A educação terapêutica e a informação dada à pessoa com diabetes parece ser importante nesta doença de prevalência crescente. Estudar a efetividade da informação escrita dada ao utente diabético, após 6 meses, no controle e na adesão terapêutica.

Método: Ensaio clínico não farmacológico. Amostra aleatorizada de diabéticos de 65 médicos de família voluntários, distribuídos pelas cinco regiões de Portugal continental. $\mathrm{Na}$ primeira consulta, as pessoas foram aleatorizadas (em grupos de intervenção com folhetos validados e grupo controle) e foi reforçada a leitura do folheto nas consultas de seguimento até 6 meses. Foram recolhidas as seguintes informações: $\mathrm{HbA}_{1 c}$, glicemias em domicílio, peso, altura, perímetro abdominal, pressão arterial, cigarros fumados, atividade física praticada, adesão terapêutica, medicamentos tomados, tempo de evolução da diabetes, idade, sexo e educação. Estatística descritiva e inferencial.

Resultados: Das 709 pessoas recrutadas, foram estudadas 702, sem diferenças significativas para as variáveis epidemiológicas medidas. Aos seis meses da intervenção, a adesão à terapêutica farmacológica melhorou mais no grupo que recebeu folheto $(\mathrm{p}=0,034)$, nas pessoas com menos de 65 anos $(\mathrm{p}=0,027)$, com diabetes há cinco anos ou menos $(\mathrm{p}=0,010)$, com formação de até quatro anos $(\mathrm{p}=0,030)$ e até nove anos $(\mathrm{p}=0,006)$ e com a $\mathrm{HbA}_{1 c} \geq 7 \%$ no início do estudo $(\mathrm{p}=0,008)$.

Conclusão: Folhetos dados nos cuidados de saúde primários a pessoas com diabetes tipo 2 podem beneficiar a 
adesão terapêutica a curto prazo, nomeadamente em pessoas mais novas e com menor formação.

Palavras-chave: Diabetes Mellitus. Adesão à Medicação. Educação de Pacientes como Assunto.

\section{References}

1. International Diabetes Federation. IDF diabetes atlas. 7. ed. Brussels: International Diabetes Federation; 2015 [cited 2016 Feb 22]. Available from: http://www.diabetesatlas.org/.

2. Effect of intensive blood-glucose control with metformin on complications in overweight patients with type 2 diabetes (UKPDS 34). UK Prospective Diabetes Study (UKPDS) Group. Lancet. 1998; 352(9131):854-65.

3. Ismail-Beigi F, Craven T, Banerji MA, Basile J, Calles J, Cohen RM, et al.; ACCORD trial group. Effect of intensive treatment of hyperglycaemia on microvascular outcomes in type 2 diabetes: an analysis of the ACCORD randomised trial. Lancet. 2010; 376(9739):419-30.

4. Duckworth W, Abraira C, Moritz T, Reda D, Emanuele N, Reaven PD, et al.; VADT Investigators. Glucose control and vascular complications in veterans with type 2 diabetes. N Engl J Med. 2009; 360(2):129-39.

5. ADVANCE Collaborative Group, Patel A, MacMahon S, Chalmers J, Neal $\mathrm{B}$, Billot $\mathrm{L}$, et al. Intensive blood glucose control and vascular outcomes in patients with type 2 diabetes. N Engl J Med. 2008; 358(24):2560-72.

6. Intensive blood-glucose control with sulphonylureas or insulin compared with conventional treatment and risk of complications in patients with type 2 diabetes (UKPDS 33). UK Prospective Diabetes Study (UKPDS) Group. Lancet. 1998; 352(9131):837-53.

7. Ohkubo Y, Kishikawa H, Araki E, Miyata T, Isami S, Motoyoshi S, et al. Intensive insulin therapy prevents the progression of diabetic microvascular complications in Japanese patients with non-insulin-dependent diabetes mellitus: a randomized prospective 6-year study. Diabetes Res Clin Pract. $1995 ; 28(2): 103-17$

8. McEwen LN, Kim C, Karter AJ, Haan MN, Ghosh D, Lantz PM, et al. Risk factors for mortality among patients with diabetes: the Translating Research Into Action for Diabetes (TRIAD) Study. Diabetes Care. 2007; 30(7):1736-41.

9. Tkáč I. Effect of intensive glycemic control on cardiovascular outcomes and all-cause mortality in type 2 diabetes: overview and metaanalysis of five trials. Diabetes Res Clin Pract. 2009; 86(Suppl 1):S57-62.

10. Tight blood pressure control and risk of macrovascular and microvascular complications in type 2 diabetes: UKPDS 38. UK Prospective Diabetes Study Group. BMJ. 1998; 317(7160):703-13.

11. ACCORD Study Group, Cushman WC, Evans GW, Byington RP, Goff DC $\mathrm{Jr}$, Grimm RH Jr, et al. Effects of intensive blood-pressure control in type 2 diabetes mellitus. N Engl J Med. 2010; 362(17):1575-85.

12. Cholesterol Treatment Trialists' (CTT) Collaborators, Kearney PM, Blackwell L, Collins R, Keech A, Simes J, et al. Efficacy of cholesterol-lowering therapy in 18,686 people with diabetes in 14 randomised trials of statins: a metaanalysis. Lancet. 2008; 371(9607):117-25.

13. Hughes JR. A quantitative estimate of the clinical significance of treating tobacco dependence. Am J Prev Med. 2010; 39(3):285-6.

14. Shaya FT, Yan X, Lin PJ, Simoni-Wastila L, Bron M, Baran R, et al. US trends in glycemic control, treatment, and comorbidity burden in patients with diabetes. J Clin Hypertens (Greenwich). 2010; 12(10):826-32.

15. Pablos-Velasco P, Parhofer KG, Bradley C, Eschwège E, Gönder-Frederick L, Maheux P, et al. Current level of glycaemic control and its associated factors in patients with type 2 diabetes across Europe: data from the PANORAMA study. Clin Endocrinol (Oxf). 2014; 80(1):47-56

16. Stone MA, Charpentier G, Doggen K, Kuss O, Lindblad U, Kellner C, et al Quality of care of people with type 2 diabetes in eight European countries: findings from the Guideline Adherence to Enhance Care (GUIDANCE) study. Diabetes Care. 2013; 36(9):2628-38.

17. Grant RW, Cagliero E, Dubey AK, Gildesgame C, Chueh HC, Barry MJ, et al. Clinical inertia in the management of type 2 diabetes metabolic risk factors. Diabet Med. 2004; 21(2):150-5.

18. Handelsman Y, Jellinger PS. Overcoming obstacles in risk factor management in type 2 diabetes mellitus. J Clin Hypertens (Greenwich). 2011; 13(8):613-20.

19. Morris AD, Boyle DI, McMahon AD, Greene SA, MacDonald TM, Newton RW. Adherence to insulin treatment, glycaemic control, and ketoacidosis in insulin-dependent diabetes mellitus. The DARTS/MEMO Collaboration. Diabetes Audit and Research in Tayside Scotland. Medicines Monitoring Unit. Lancet. 1997; 350(9090):1505-10.

20. Donnan PT, MacDonald TM, Morris AD. Adherence to prescribed oral hypoglycaemic medication in a population of patients with type 2 diabetes: a retrospective cohort study. Diabet Med. 2002; 19(4):279-84.

21. Shultz JA, Sprague MA, Branen LJ, Lambeth S. A comparison of views of individuals with type 2 diabetes mellitus and diabetes educators about barriers to diet and exercise. J Health Commun. 2001; 6(2):99-115.

22. Hankó B, Kázmér M, Kumli P, Hrágyel Z, Samu A, Vincze Z, et al. Selfreported medication and lifestyle adherence in Hungarian patients with type 2 diabetes. Pharm World Sci. 2007; 29(2):58-66.

23. Zhao G, Ford ES, Li C, Balluz LS. Physical activity in U.S. older adults with diabetes mellitus: prevalence and correlates of meeting physical activity recommendations. J Am Geriatr Soc. 2011; 59(1):132-7.

24. Norris SL, Lau J, Smith SJ, Schmid CH, Engelgau MM. Self-management education for adults with type 2 diabetes: a meta-analysis of the effect on glycemic control. Diabetes Care. 2002; 25(7):1159-71.

25. Gary TL, Genkinger JM, Guallar E, Peyrot M, Brancati FL. Meta-analysis of randomized educational and behavioral interventions in type 2 diabetes. Diabetes Educ. 2003; 29(3):488-501.

26. Norris SL, Engelgau MM, Narayan KM. Effectiveness of self-management training in type 2 diabetes: a systematic review of randomized controlled trials. Diabetes Care. 2001; 24(3):561-87.

27. Gagliardino JJ, Etchegoyen G; PENDID-LA Research Group. A model educational program for people with type 2 diabetes: a cooperative Latin American implementation study (PEDNID-LA). Diabetes Care. 2001; 24(6):1001-7.

28. Goldstein MG, Whitlock EP, DePue J; Planning Committee of the Addressing Multiple Behavioral Risk Factors in Primary Care Project. Multiple behavioral risk factor interventions in primary care: summary of research evidence. Am J Prev Med. 2004; 27(2 Suppl):61-79.

29. Nicolson DJ, Knapp P, Raynor DK, Spoor P. Written information about individual medicines for consumers. Cochrane Database Syst Rev. 2009; (2):CD002104

30. McPherson CJ, Higginson IJ, Hearn J. Effective methods of giving information in cancer: a systematic literature review of randomized controlled trials. J Public Health Med. 2001; 23(3):227-34.

31. Fox R. Informed choice in screening programmes: do leaflets help? A critical literature review. J Public Health (Oxf). 2006; 28(4):309-17.

32. Nieuwlaat R, Wilczynski N, Navarro T, Hobson N, Jeffery R, Keepanasseril $A$, et al. Interventions for enhancing medication adherence. Cochrane Database Syst Rev. 2014; (11):CD000011.

33. Stacey D, Légaré F, Col NF, Bennett CL, Barry MJ, Eden KB, et al. Decision aids for people facing health treatment or screening decisions. Cochrane Database Syst Rev. 2014; (1):CD001431.

34. Albero R, Acha J, Sanz A, Casamayor L, Playán J, Boudet A. [Metabolic improvement of diabetes mellitus through pamphlets on the norms of selfmonitoring control measures]. Aten Primaria. 1993; 12(8):475-8.

35. Chen HS, Wu TE, Jap TS, Chen RL, Lin HD. Effects of health education on glycemic control during holiday time in patients with type 2 diabetes mellitus. Am J Manag Care. 2008; 14(1):45-51.

36. Selea A, Sumarac-Dumanović M, Pesić M, Suluburić D, StamenkovićPejković D, Cvijović G, et al. The effects of education with printed material on glycemic control in patients with diabetes type 2 treated with different therapeutic regimens. Vojnosanit Pregl. 2011; 68(8):676-83.

37. Heisler M, Choi H, Palmisano G, Mase R, Richardson C, Fagerlin A, et al. Comparison of community health worker-led diabetes medication decisionmaking support for low-income Latino and African American adults with diabetes using e-health tools versus print materials: a randomized controlled trial. Ann Intern Med. 2014; 161(10 Suppl):S13-22.

38. King AB, Wolfe GS, Armstrong DU. Evaluation of a patient education booklet (SimpleStart) effect on postprandial glucose control in type 2 diabetes. Diabetes Technol Ther. 2007; 9(3):241-5.

39. Weymiller AJ, Montori VM, Jones LA, Gafni A, Guyatt GH, Bryant SC, et al. Helping patients with type 2 diabetes mellitus make treatment decisions: statin choice randomized trial. Arch Intern Med. 2007; 167(10):1076-82.

40. Miranda P. Impacto da informação escrita no controlo da diabetes mellitus tipo 2 no centro de Portugal. In: $16^{\circ}$ Congresso Nacional de Medicina Familiar, Funchal, 3 de outubro de 2011.

41. Núcleo de Exercício e Saúde, Faculdade de Motricidade Humana, Universidade Técnica de Lisboa, editor. Aconselhamento para a actividade física PACE. Oeiras: C.M; 2003. 
42. Delgado AB, Lima ML. Contributo para a validação concorrente de uma medida de adesão aos tratamentos. Psicol Saúde Amp Doenças. 2001; 2(2):81-100.

43. Harvard T.H. Chan School of Public Health. Assessing and developing health materials [cited 2015 Dec 11]. Available from: http://www.hsph.harvard. edu/healthliteracy/practice/innovative-actions/.

44. NHS BG. Tools and resources: patient information [cited 2016 Mar 6]. Available from: http://www.nhsidentity.nhs.uk/tools-and-resources/patientinformation.

45. Martins AC. Adesão à terapêutica medicamentosa em doentes com Diabetes mellitus tipo 2: um estudo no ACES Almada e Seixal. 2014 [cited 2016 Jul 3]. Available from: https://run.unl.pt/handle/10362/14648.

46. Gimenes HT, Zanetti ML, Haas VJ. Factors related to patient adherence to antidiabetic drug therapy. Rev Lat Am Enfermagem. 2009; 17(1):46-51.

47. Faria HT, Santos MA, Arrelias CC, Rodrigues FF, Gonela JT, Teixeira CR, et al. Adherence to diabetes mellitus treatments in family health strategy units. Rev Esc Enferm USP. 2014; 48(2):257-63.

48. Jarvis J, Skinner TC, Carey ME, Davies MJ. How can structured selfmanagement patient education improve outcomes in people with type 2 diabetes? Diabetes Obes Metab. 2010; 12(1):12-9.

49. Minet L, Møller S, Vach W, Wagner L, Henriksen JE. Mediating the effect of self-care management intervention in type 2 diabetes: a meta-analysis of 47 randomised controlled trials. Patient Educ Couns. 2010; 80(1):29-41.

50. Loveman E, Frampton GK, Clegg AJ. The clinical effectiveness of diabetes education models for type 2 diabetes: a systematic review. Health Technol Assess. 2008; 12(9):1-116.

51. Tunis SR, Stryer DB, Clancy CM. Practical clinical trials: increasing the value of clinical research for decision making in clinical and health policy. JAMA. 2003; 290(12):1624-32.

52. Bruce DG, Davis WA, Cull CA, Davis TM. Diabetes education and knowledge in patients with type 2 diabetes from the community: the Fremantle Diabetes Study. J Diabetes Complications. 2003; 17(2):82-9.

53. Bautista-Martinez S, Aguilar-Salinas CA, Lerman I, Velasco ML, Castellanos $\mathrm{R}$, Zenteno E, et al. Diabetes knowledge and its determinants in a Mexican population. Diabetes Educ. 1999; 25(3):374-81.

54. Ramanath K, Santhosh Y. Impact of clinical pharmacist provided patient education on QOL outcome in type II diabetes mellitus in rural population. Asian J Pharm Clin Res. 2011; 4(4):15-20.

55. Ho PM, Rumsfeld JS, Masoudi FA, McClure DL, Plomondon ME, Steiner JF, et al. Effect of medication nonadherence on hospitalization and mortality among patients with diabetes mellitus. Arch Intern Med. 2006; 166(17):1836-41.

56. Rhee MK, Slocum W, Ziemer DC, Culler SD, Cook CB, El-Kebbi IM, et al. Patient adherence improves glycemic control. Diabetes Educ. 2005; 31(2):240-50.

57. Guillausseau PJ. Influence of oral antidiabetic drugs compliance on metabolic control in type 2 diabetes. A survey in general practice. Diabetes Metab. 2003; 29(1):79-81.

58. Kassahun T, Eshetie T, Gesesew H. Factors associated with glycemic control among adult patients with type 2 diabetes mellitus: a cross-sectional survey in Ethiopia. BMC Res Notes. 2016; 9:78.

59. DiBonaventura M, Wintfeld N, Huang J, Goren A. The association between nonadherence and glycated hemoglobin among type 2 diabetes patients using basal insulin analogs. Patient Prefer Adherence. 2014; 8:873-82.

60. Aikens JE, Piette JD. Longitudinal association between medication adherence and glycaemic control in type 2 diabetes. Diabet Med. 2013; 30(3):338-44.
61. Sapkota S, Brien J, Greenfield J, Aslani P. A systematic review of interventions addressing adherence to anti-diabetic medications in patients with type 2 diabetes: impact on adherence. PLoS One. 2015; 10(2):e0118296.

62. Tiv M, Viel JF, Mauny F, Eschwège E, Weill A, Fournier C, et al. Medication adherence in type 2 diabetes: the ENTRED study 2007, a French Populationbased study. PLoS One. 2012; 7(3):e32412.

63. Hepke KL, Martus MT, Share DA. Costs and utilization associated with pharmaceutical adherence in a diabetic population. Am J Manag Care. 2004; 10(2 Pt 2):144-51.

64. Sokol MC, McGuigan KA, Verbrugge RR, Epstein RS. Impact of medication adherence on hospitalization risk and healthcare cost. Med Care. 2005; 43(6):521-30

65. Lee WC, Balu S, Cobden D, Joshi AV, Pashos CL. Prevalence and economic consequences of medication adherence in diabetes: a systematic literature review. Manag Care Interface. 2006; 19(7):31-41.

66. Bonora E. Postprandial peaks as a risk factor for cardiovascular disease: epidemiological perspectives. Int J Clin Pract Suppl. 2002; (129):5-11.

67. Kearney ML, Thyfault JP. Exercise and postprandial glycemic control in type 2 diabetes. Curr Diabetes Rev. 2016; 12(3):199-210.

68. Benavente A, Rosa A, Costa AF, Ávila P. A literacia em Portugal: resultados de uma pesquisa extensiva e monográfica. Fundação Calouste Gulbenkian, Conselho Nacional de Educação; 1996 [cited 2016 Feb 25]. 430 p. Available from: http://www.cnedu.pt/pt/publicacoes/estudos-e-relatorios/ outros/799-a-literacia-em-portugal-resultados-de-uma-pesquisa-extensivae-monografica.

69. Gomes MC, Ávila P, Sebastião J, Costa AF. Novas análises dos níveis de literacia em Portugal: comparações diacrónicas e internacionais. In: Actas do IV Congresso Português de Sociologia - Sociedade portuguesa: passados recentes. Lisboa; 2000.

70. Pignone M, DeWalt DA, Sheridan S, Berkman N, Lohr KN. Interventions to improve health outcomes for patients with low literacy. A systematic review. J Gen Intern Med. 2005; 20(2):185-92

71. Bailey SC, Brega AG, Crutchfield TM, Elasy T, Herr H, Kaphingst K, et al. Update on health literacy and diabetes. Diabetes Educ. 2014; 40(5):581-604.

72. Taggart J, Williams A, Dennis S, Newall A, Shortus T, Zwar N, et al. A systematic review of interventions in primary care to improve health literacy for chronic disease behavioral risk factors. BMC Fam Pract. 2012; 13:49.

73. Colleran KM, Starr B, Burge MR. Putting diabetes to the test: analyzing glycemic control based on patients' diabetes knowledge. Diabetes Care. 2003; 26(7):2220-1.

74. He X, Wharrad HJ. Diabetes knowledge and glycemic control among Chinese people with type 2 diabetes. Int Nurs Rev. 2007; 54(3):280-7.

75. Rodrigues F, Dias P. Avaliação do conhecimento e controlo da doença, por parte de indivíduos com diabetes mellitus. Bioanálise. 2007; 4(2):51-5.

76. Kreuter MW, Strecher VJ, Glassman B. One size does not fit all: the case for tailoring print materials. Ann Behav Med. 1999; 21(4):276-83.

77. Noar SM, Benac CN, Harris MS. Does tailoring matter? Meta-analytic review of tailored print health behavior change interventions. Psychol Bull. 2007; 133(4):673-93

78. Steinsbekk A, Rygg L $\varnothing$, Lisulo M, Rise MB, Fretheim A. Group based diabetes self-management education compared to routine treatment for people with type 2 diabetes mellitus. A systematic review with meta-analysis. BMC Health Serv Res. 2012; 12:213. 